University of New Hampshire

University of New Hampshire Scholars' Repository

Faculty Publications

$5-1-2009$

\title{
The Northern Eurasia Earth Science Partnership: An Example of Science Applied to Societal Needs
}

\author{
Pavel Ya. Groisman \\ NOAA National Centers for Environment Information \\ Elizabeth A. Clark \\ Vladimir M. Kattsov \\ Dennis P. Lettenmaier \\ Irina N. Sokolik
}

See next page for additional authors

Follow this and additional works at: https://scholars.unh.edu/faculty_pubs

Comments

This is an article published by American Meteorological Society (AMS) in Bulletin of the American Meteorological Society in 2009, available online: https://dx.doi.org/10.1175/2008BAMS2556.1

\section{Recommended Citation}

Groisman, P.Y., E.A. Clark, V.M. Kattsov, D.P. Lettenmaier, I.N. Sokolik, V.B. Aizen, O. Cartus, J. Chen, S. Conard, J. Katzenberger, O. Krankina, J. Kukkonen, T. Machida, S. Maksyutov, D. Ojima, J. Qi, V.E. Romanovsky, M. Santoro, C.C. Schmullius, A.I. Shiklomanov, K. Shimoyama, H.H. Shugart, J.K. Shuman, M.A. Sofiev, A.I. Sukhinin, C. Vörösmarty, D. Walker, and E.F. Wood, 2009: The Northern Eurasia Earth Science Partnership: An Example of Science Applied to Societal Needs. Bull. Amer. Meteor. Soc., 90, 671-688.

This Article is brought to you for free and open access by University of New Hampshire Scholars' Repository. It has been accepted for inclusion in Faculty Publications by an authorized administrator of University of New Hampshire Scholars' Repository. For more information, please contact Scholarly.Communication@unh.edu. 


\section{Authors}

Pavel Ya. Groisman, Elizabeth A. Clark, Vladimir M. Kattsov, Dennis P. Lettenmaier, Irina N. Sokolik, Vladimir B. Aizen, Oliver Cartus, Jiquan Chen, Susan Conard, John Katzenberger, Olga Krankina, Jaakko Kukkonen, Toshinobu Machida, Shamil Maksyutov, Dennis Ojima, Jiaguo Qi, Vladimir E. Romanovsky, Maurizio Santoro, Christiane C. Schmullius, Alexander I. Shiklomanov, Kou Shimoyama, Herman H. Shugart, Jacquelyn K. Shuman, and Mikhail A. Sofiev 


\section{THE NORTHERN EURASIA EARTH SCIENCE PARTNERSHIP}

\section{An Example of Science Applied to Societal Needs}

by Pavel Ya. Groisman, Elizabeth A. Clark, Vladimir M. Kattsov, Dennis P. Lettenmaier, Irina N. Sokolik, Vladimir

B. Aizen, Oliver Cartus, Jiquan Chen, Susan Conard, John Katzenberger, Olga Krankina, Jaakko Kukkonen, Toshinobu Machida, Shamil Maksyutov, Dennis Ojima, Jiaguo QI, Vladimir E. Romanovsky, Maurizio Santoro, Christiane C. Schmullius, Alexander I. Shiklomanov, Kou Shimoyama, Herman H. Shugart, Jacquelyn K. Shuman, Mikhail A. Sofiev, Anatoly I. Sukhinin, Charles Vörösmarty, Donald Walker, and Eric F. Wood

An international project aims to better understand and quantify feedbacks between northern Eurasia and global climate.

Fig. I. NEESPI study area is loosely defined as the region between $15^{\circ} \mathrm{E}$ in the west, the Pacific Coast in the east, $40^{\circ} \mathrm{N}$ in the south, and the Arctic Ocean coastal zone in the north. Territory of the former Soviet Union, Fennoscandia, Eastern Europe, Mongolia, and north China are all included in this area. Moderate Resolution Imaging Spectroradiometer (MODIS) I-km true color composite from 20 to 28 Aug 2004 data for the NEESPI research domain with shaded relief adjustment using the Shuttle Radar Topography Mission (SRTM) global 30 arc-second (GTOPO30) elevation dataset. Green corresponds to vegetated land. Light brown and

W ithin northern Eurasia, dramatic climatic, environmental, and socioeconomic changes have occurred during the past century. These include floods and droughts, forest fires and dust storms, massive land and water management projects, social unrest, and revolutions. Some of these changes are of such scope that they not only have regional but also global implications via the climate system.

The Northern Eurasian Earth Science Partnership Initiative (NEESPI), whose domain of approximately $28.6 \times 10^{6} \mathrm{~km}^{2}$ (Fig. 1) accounts for roughly $60 \%$ of the terrestrial land area north of $40^{\circ} \mathrm{N}$, was formed to

yellow indicate sparse vegetation and arid areas, respectively. Positions of a few major cities within the domain are marked in red. Produced by Dr. Mutlu Ozdogan (University of Wisconsin-Madison). 
better understand the nature of global climate feedbacks to land processes and anthropogenic activities in the region. The ecosystems within this vast region vary substantially-from tundra in the north to semiarid grassland and deserts in the south. Northern Eurasia has land cover unique to cold regions, including roughly $70 \%$ of the Earth's boreal forest and greater than two-thirds of the Earth's permafrost.

The region is undergoing rapid changes, resulting from both a warming climate and socioeconomic changes. Lugina et al. (2006) reported that surface air temperature averaged over northern Eurasia increased by $1.4 \mathrm{~K}$ across northern Eurasia-almost double the average for the global land areas-over the past $127 \mathrm{yr}$ (Fig. 2). Given the large area of the region, these changes can have a global influence as a result of associated changes in atmospheric circulation and through biogeophysical and biogeochemical feedbacks. In particular, interactions of the climate of northern Eurasia with the global system have tremendous implications for global carbon management because more than half of all terrestrial carbon is stored in the boreal forest and tundra zones (mostly in soil), and two-thirds of these zones fall within northern Eurasia. Unfortunately, little is known about how this cold, carbon-rich region functions and the specifics of its interactions with the global system. In response to this deficiency of knowledge, NEESPI was formed in 2004 to better understand and quantify climate feedbacks within and beyond northern Eurasia.

NEESPI views the global Earth system as functioning through the interaction of biogeochemical, energy, and water cycles, and human activity (Groisman and Bartalev 2007). Biogeochemical cycles influence atmospheric and oceanic composition, soil formation, and biome evolution. Energy and water cycle processes define the Earth's climate system as we know it. Human activity — beginning with the establishment of agriculture, forest harvest, and mineral extraction, and continuing through industrial developmentoriginally affected regional environments and now alters the global climate system. NEESPI prioritizes scientific research that addresses processes with direct feedback to the global system and those of greatest importance to society in three main areas: terrestrial biogeochemical cycles, energy and water cycles, and society-environment interactions. Although this paper focuses primarily on the scientific aspects of NEESPI, we also address some related societal and policy issues. We conclude with a brief discussion of NEESPI data and information acquisition, and an ongoing transition within NEESPI from data collection and process studies to regional projections.

To date, the NEESPI has brought together more than 125 individually funded projects in the United States, Russia, China, European Union, Japan, and Canada. On an intergovernmental level, the NEESPI research foci on regional modeling and studies of climate impacts and adaptation capacity were included in a Memorandum of Understanding for Collaboration in the Fields of Meteorology, Hydrology, and Oceanography between the U.S. National Oceanic and Atmospheric Administration (NOAA) and the Russian Federal Service for Hydrometeorology and Environmental Monitoring. NEESPI has been also recognized by major international Earth science programs and projects: the Earth System Science Partnership Program (ESSP), through its Global Water System Project, Global Land Project, and Global Carbon Project; and the ESSP-parent
AFFILIATIONS: GROISMAN-UCAR, NOAA/National Climatic Data Center, Asheville, North Carolina; CLARK AND LetTenMaIERUniversity of Washington, Seattle, Washington; KATTSOVVoeikov Main Geophysical Observatory, St. Petersburg, Russia; SOKOLIK-Georgia Institute for Technology, Atlanta, Georgia; AIZEN-University of Idaho, Moscow, Idaho; CARTUS AND SCHMULLIUS-Friedrich Schiller University, Jena, Germany; CHENUniversity of Toledo, Toledo, Ohio; CONARD-USDA Forest Service, Arlington, Virginia; KATZEnBERGeR-Aspen Global Change Institute, Aspen, Colorado; KranKINA-Oregon State University, Corvallis, Oregon; KUKKONEN AND SOFIEV-Finnish Meteorological Institute, Helsinki, Finland; MACHIDA AND MAKsYutov-National Institute for Environmental Sciences, Tsukuba, Japan; OJıMA-The H. John Heinz III Center for Science, Economics, and the Environment, Washington, D.C.; Q1-Michigan State University, East Lansing, Michigan; Romanovsky AND WALKER-University of Alaska, Fairbanks, Alaska; SANTORO-Gamma Remote Sensing, Gümligen,
Switzerland; SHIKLOMANOV AND VÖRÖSMARTY - University of New Hampshire, Durham, New Hampshire; SHIMOYAMA-Hokkaido University, Sapporo, Japan; SHUGART AND SHUMAN-University of Virginia, Charlottesville, Virginia; SUKHININ-Forest Institute, Siberian Branch of the Russian Academy of Sciences, Krasnoyarsk, Russia; WoOD-Princeton University, Princeton, New Jersey. CORRESPONDING AUTHOR: Pavel Ya. Groisman, UCAR at NOAA/National Climatic Data Center, 151 Patton Avenue, Asheville, NC 28801

E-mail: pasha.groisman@noaa.gov

The abstract for this article can be found in this issue, following the table of contents.

DOI:10.1175/2008BAMS2556.1

In final form 25 November 2008

(C2009 American Meteorological Society 
International Geosphere-Biosphere Programme, and the World Climate Research Programme's Global Energy and Water Cycle Experiment, and Climate and Cryosphere Projects.

TERRESTRIALBIOGEOCHEMICAL CYCLES. The boreal forests in the Northern Hemisphere and, in particular, the Siberian boreal forest, are thought to have a particularly strong effect on the Earth's climate. Russian boreal forests store more than a quarter of the world's terrestrial carbon in soil, wetlands, and aboveground biomass (Solomon et al. 2007). This storage is highly sensitive to global warming and is vulnerable to dramatic releases of greenhouse gases from forest fires, changes in lake and wetland dynamics, changing land cover, and thawing permafrost.

The role of fire. Fire is perhaps the most important large-scale disturbance factor in the NEESPI region. In a typical year, $0.10-0.15 \times 10^{6} \mathrm{~km}^{2}$ of forest, forest-steppe, and steppe are burned within the NEESPI region, with extremes above $0.2 \times 10^{6} \mathrm{~km}^{2}$ (approximately the size of Nebraska) in severe fire years, such as 2003. Observed increases in wildfire activity (Korovin and Zukkert 2003) and in the frequency of "fire" weather conditions (Groisman et al. 2007a) have the potential to substantially affect the carbon storage capacity of Siberian forests and may also produce as yet poorly defined feedbacks to atmospheric chemistry and radiative forcing. NEESPI research seeks to improve estimates of the effect of fire on the carbon balance under varying environmental conditions for key forest types of central Siberia, with a focus on Larix (larch) and Pinus sylvestris (Scots pine) forests (e.g., McRae et al. 2006; Ivanova et al. 2007).

Since 2000, NEESPI scientists have completed more than 20 prescribed fires in central Siberia to quantify fire behavior, direct and indirect emissions, fire's influence on the carbon cycle, and relationships of fire effects with environmental conditions (McRae et al. 2006; Ivanova et al. 2007). For a given vegetation type, emission characteristics
Fig. 2. (top) Mean annual surface air temperature anomalies during the past $127 \mathrm{yr}$ over northern Eurasia [linear trend $1.4 \mathrm{~K}(127 \mathrm{yr})^{-1}$ compared to near-global changes within zone $60^{\circ} \mathrm{S}-90^{\circ} \mathrm{N}$ [linear trend $0.84 \mathrm{~K}(127 \mathrm{yr})^{-1}$; archive of Lugina et al. 2006 updated]. The near-twofold higher rates of warming over northern Eurasia compared to the globe during the past several decades remained intact [e.g., $1.6 \mathrm{~K}(50 \mathrm{yr})^{-1}$ versus $0.81(50 \mathrm{yr})^{-1} ; 1.41 \mathrm{~K}$ $(30 \mathrm{yr})^{-1}$ versus $0.62(30 \mathrm{yr})^{-1}$ for 1958-2007 and 19782007, respectively]. (bottom) Observed and projected surface air temperature anomalies over Russia. Numbers in key are as follows: I) station data, 2) reanalyzed [40-yr European Centre for MediumRange Weather Forecasts Reanalysis (ERA-40)] data, and 3) simulated/projected by 16-member ensemble of Coupled Model Intercomparison Project, Phase 3 (CMIP3) global climate models [Special Report Emissions Scenarios (SRES) A2 scenario; Meleshko et al. 2008].
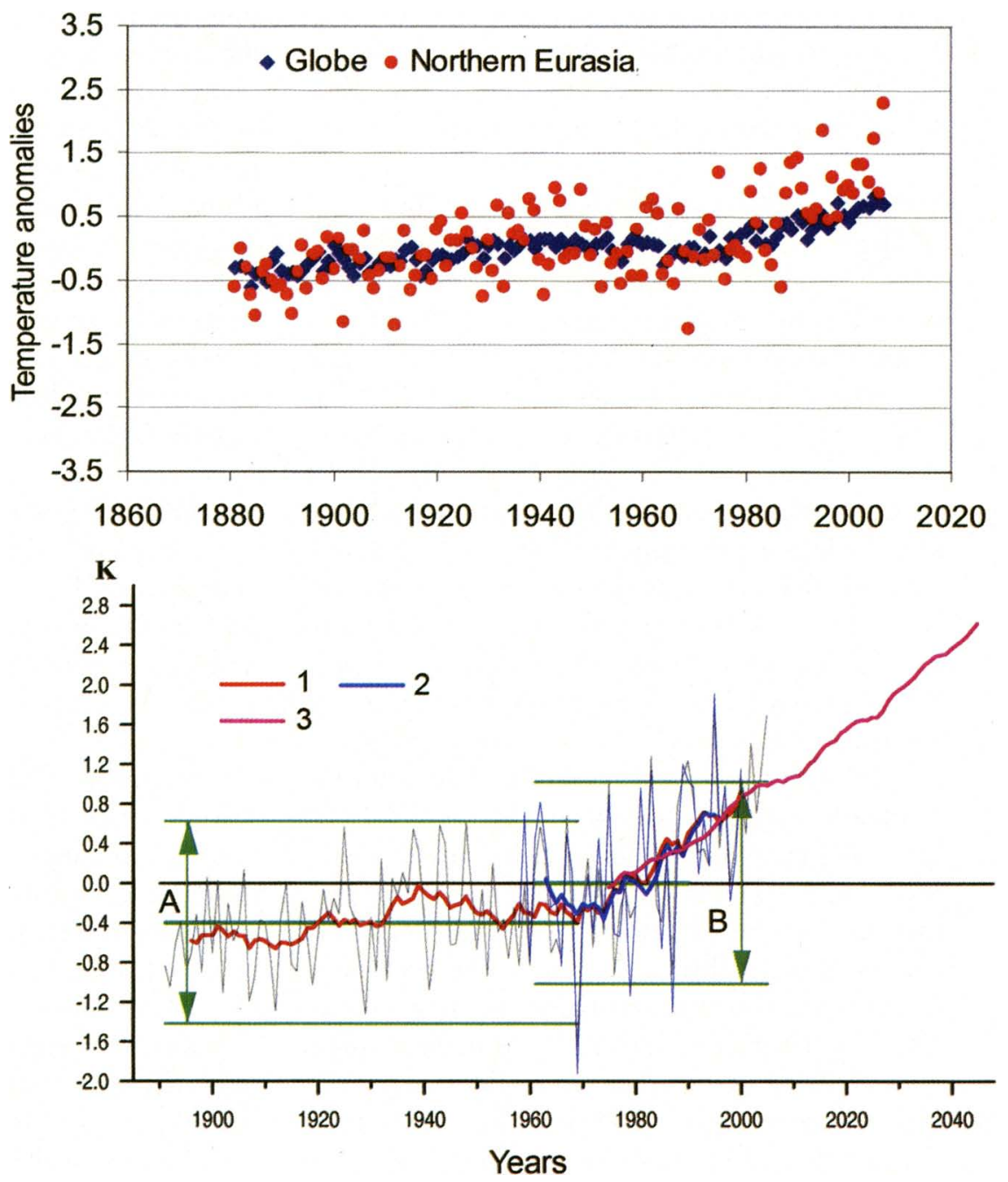
were strongly related to fire behavior characteristics and fire weather indices, providing a potential basis for estimating fuel consumption across large areas. Across the range of experimental fires in Scots pine, total fuel consumption varied by a factor of 3-4 as a function of fuel and environmental conditions at the time of the fire (McRae et al. 2006). Analyses of emission samples from these fires have provided estimates of overall combustion efficiency as well as relative emissions of $\mathrm{CO}_{2}, \mathrm{CO}$, methane, ethylene, propylene, and other greenhouse gases in smoke under a range of burning conditions (Baker and Hao 2005). In addition, burn severity and vegetation characteristics on more than 70 wildfire sites in Siberia were evaluated using aircraft-based remote sensing of active fires and analyses of both active fire and post-fire satellite and ground data. In a related study, Soja et al. (2004) integrated remote sensing data on fire occurrence, vegetation, and fuels data, estimated combustion efficiencies, and potential variability in fuel consumption to estimate the potential ranges in fire emissions for Siberia from 1998 to 2002. The results of these studies illustrate that understanding fire severity patterns and better quantifying of fuel consumption are critical components in estimating the effects of fire on the carbon cycle.

Wetland and lake dynamics. Similar to forest and tundra fires, biotic processes in lakes and wetlands in northern Eurasia play an important role in global carbon emissions, generating at least $10 \%$ of global methane emissions (Walter et al. 2006) and substantial carbon dioxide emissions (Peregon et al. 2008). Unfortunately, estimates of greenhouse gas emissions from these areas, along with the sensitivity of these emissions to rapid ongoing warming, are uncertain as a result of the sparseness of observations. Recent advances in remote sensing allow for observation of some of the key elements, such as the extent of inundated land (land areas with a zero water table depth). NEESPI scientists are currently using remotely sensed estimates of inundated extent to calibrate large-scale coupled hydrologic-biogeochemical models for the estimation of $\mathrm{CO}_{2}$ and $\mathrm{CH}_{4}$ fluxes. Bohn et al. (2007) generalized the Variable Infiltration Capacity (VIC) hydrologic model into a suite of models that now includes lake and wetland dynamics, the biosphereenergy-transfer-hydrology terrestrial ecosystem model, and the wetland methane emissions model. This framework was applied to simulate seasonal cycles and long-term trends in methane emissions over the largest bog in West Siberia, Bakchar Bog, for the past 50 yr. Projections over the same area based on GCM climate projections suggest that summer methane emissions may double by the end of this century.

Land cover/land use change and carbon fluxes. Climate and land cover changes complicate carbon sequestration estimates for northern Eurasia. Pilot estimates using the CENTURY-based modeling system forced with an anticipated future climate project a variety of changes in carbon sequestration. The net primary production (amount of organic matter stored in plant tissues annually) of forest ecosystems generally appears to increase, whereas croplands show variable patterns of change, suggesting that ecosystem responses will differ by ecosystem type (Ojima and Chuluun 2008).

The importance of understanding the space-time structure of carbon fluxes to the atmosphere has gained considerable prominence as interest in anthropogenic climate change also increases. Continuous measurement systems for atmospheric $\mathrm{CO}_{2}$ concentrations were installed and operated for several years along the Lena River (Georgiadi and Zolotokrylin 2007), in European Russia (Kurbatova et al. 2008), along a latitudinal transect from Bialystok, Poland, to Cherskiy, northeast Yakutia, Russia (Schulze et al. 2002), and on a network of flux towers in West Siberia. West Siberia was selected because it is a flat plain; the land cover structure is rather simple, and carbon fluxes to/from the underlying ecosystems (boreal forest, bogs, and tundra) can be substantial and changing. Carbon dioxide observation sites in this area were selected to optimize the observation network for inverse model error reduction as well as for infrastructure, logistics, and manpower (Peregon et al. 2008). In the southern path of West Siberia, seasonal variations in $\mathrm{CO}_{2}$ flux in 2005 were estimated by using an inverse model (Patra et al. 2005). In winter, the $\mathrm{CO}_{2}$ flux was almost zero or weakly positive (emission). Absorption (negative flux) of $\mathrm{CO}_{2}$ began in May and increased to a maximum in June.

Permafrost thaw. Permanently frozen soils are susceptible to widespread thaw and degradation as a result of rising surface temperatures. Permafrost thaw, which is already occurring at the southern limits of the permafrost zone, can dramatically alter ecosystems and has adverse effects on infrastructure (Romanovsky et al. 2007, 2008). Thawing also releases greenhouse gases, in quantities potentially significant to the global carbon cycle, from recently frozen and inactive organic carbon pools in the permafrost zone. Deepening of the active (seasonally thawed) layer above the 
permafrost, resulting from warming air temperatures, could dramatically alter streamflow and lake and wetland dynamics. As part of NEESPI, permafrost scientists from 14 institutions in Eurasia and Alaska have joined their efforts to merge permafrost temperature observations in Russia, Kazakhstan, the United States, and Mongolia (Romanovsky et al. 2008). They have established a modern permafrost monitoring network, with more than 100 boreholes in Eurasia already equipped with standard temperature sensors and loggers, In 2006-08, the data from many of these sites became readily available (Fig. 3). Some preliminary work has been conducted to predict the response of regional permafrost changes to future climate warming (Fig. 4; Romanovsky et al. 2008). According to this model, by the end of the twenty-first century, currently discontinuous permafrost (temperatures between $0^{\circ}$ and $-2.5^{\circ} \mathrm{C}$ ) will have warmed to the point of active thaw. Romanovky et al. $(2007,2008)$ projected that permafrost degradation will be most significant in west and south Siberia. These simulations suggest that almost all permafrost in Europe will be thawing by the end of the twentyfirst century.

Ideally, permafrost models would account for feedbacks between permafrost thaw and climate, vegetation, and surface and subsurface hydrology by allowing for dynamic interactions rather than prescribed conditions. These surface processes could either delay or amplify environmental changes, including permafrost thaw itself, as well as changes in $\mathrm{CO}_{2}$ and methane emissions from thawing soils and the Arctic shelf (cf. Dutta et al. 2006; Shakhova et al. 2007). Ongoing NEESPI projects are beginning to incorporate cold land processes into hydrological and climatic models for the Eurasian high latitudinal domain. Early results show both nonlinearities of climatic changes as a result of interactions with permafrost (Lawrence et al. 2008) and substantial improvements in the ability of hydrological models to reproduce the runoff variations of major Siberian rivers that cross the permafrost areas (Adam and Lettenmaier 2008).

ENERGY AND WATER CYCLES. NEESPI studies of the energy and water cycles focus on better representing the surface radiation budget, turbulent heat fluxes, and evapotranspiration using flux towers, and heat balance and pan evaporation networks across the former Soviet Union (Groisman and Bartalev 2007). NEESPI also focuses on how ongoing climate and land cover changes can be expected to affect the surface water and energy cycles.

Surface albedo. One component of the energy cycle that is affected by changes in land cover is surface albedo. Warming driven by reduced surface albedo, in turn driven by the expansion of dark coniferous forests, could significantly outweigh any coincident decrease in greenhouse gas-related warming (e.g., Betts 2000). Even the conversion of deciduous larch 

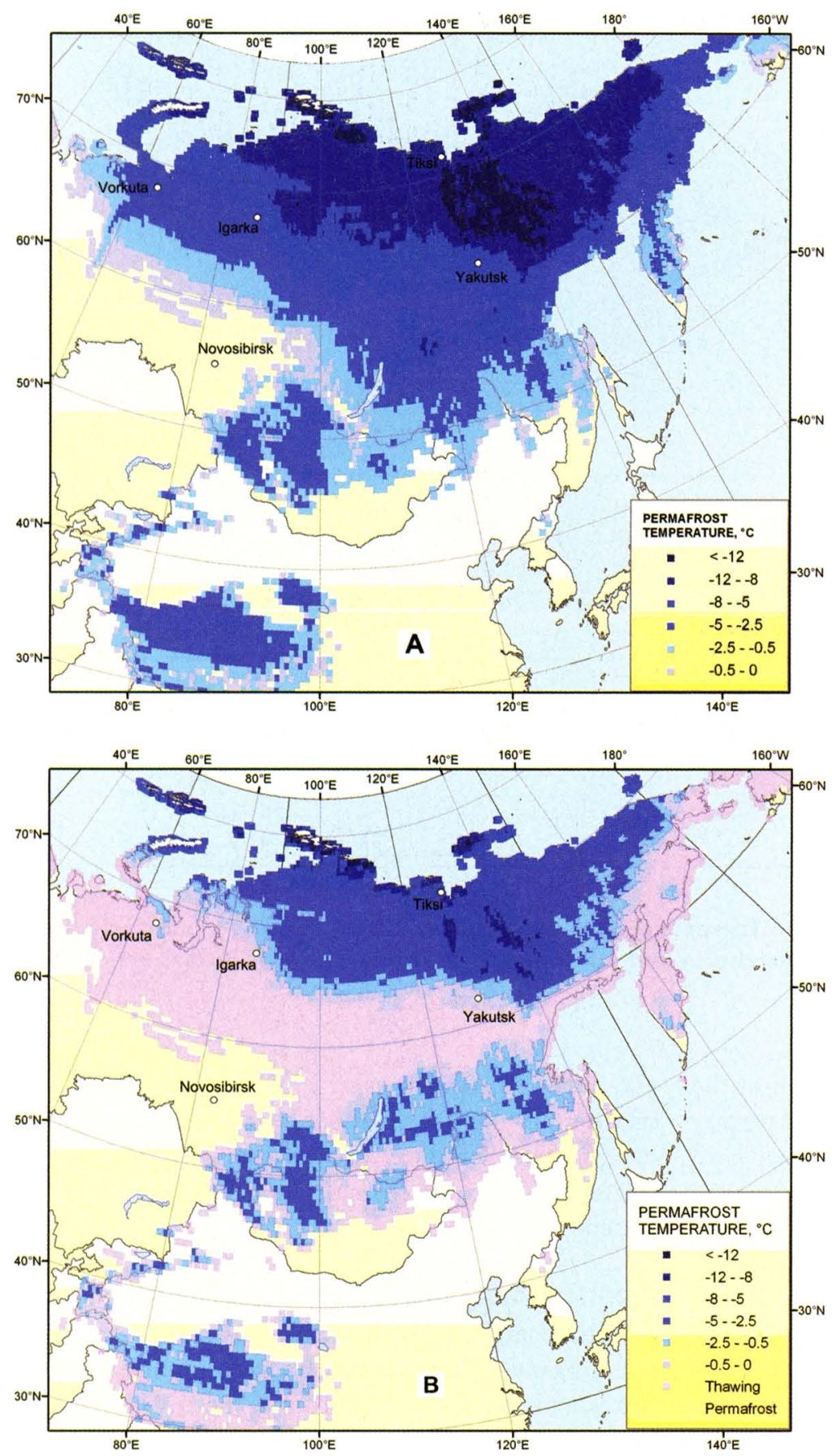

Fig. 4. Modeled permafrost temperatures in northern Eurasia (mean annual temperature at the permafrost surface) averaged over (a) 1980-2000 and (b) 2080-2100 time intervals (Romanovsky et al. 2007, 2008).

forest, which currently and uniquely covers large expanses of the Siberian boreal forest zones, to "dark conifer forests" (spruce and fir) could produce significant albedo changes (Shugart et al. 2006). This implies a potential positive feedback cycle: a warmer climate accelerates the natural succession from larch to dark conifer forest; the resultant albedo change then pro- motes additional climate warming. On the other hand, replacement of the forest by forest-steppe and steppe might lead to significant cooling as a result of albedo increase (Vygodskaya et al. 2007). NEESPI researchers are attempting to predict how the forest composition will respond to future climate changes and are exploring the resulting feedbacks to the water and energy cycles. A forest stand composition and biomass model, which simulates birth, growth, and death of the interactive individual trees in a forest stand, has been applied across the boreal zone of Eurasia (Yan and Shugart 2005).

Glaciers and snow cover. Both the energy and water cycles interact strongly with glaciers and snow cover. Northern Eurasian glaciers have retreated rapidly over the last 150 years, since the end of the "Little Ice Age." These changes have accelerated since the 1970s. This retreat is believed to be a result of an increase in air temperature as well as changes in the snow/rain partitioning of precipitation in alpine areas (Aizen et al. 2000). The glacier retreat and accelerated seasonal snowmelt affect the hydrological cycle of downstream watersheds and may cause lowland desertification, glacier outburst floods, and mudflows in the middle and upper river reaches (e.g., in Central Asia). The Tien Shan glaciers of Central Asia lost $6.4 \%$ of their total area from 1943 to 1973. Their retreat accelerated to a total area loss of $\sim 10 \%$ from 1973 to 2007 and in the last $20 \mathrm{yr}$, the surface of some glaciers has lowered by more than $100 \mathrm{~m}$ (Aizen et al. 2006a).

Among the components of the cryosphere, snow cover controls the energy and water balances of the region and terrestrial ecosystems and is the most dynamic. Seasonal snow cover, with durations from 1 week to 10 months, occurs across most of the NEESPI domain. Several NEESPI projects are devoted to monitoring and studying the effects of changes in snow cover. We found that the duration of 
snow cover generally decreased over the past $40 \mathrm{yr}$, with no systematic changes in midwinter snow cover but a systematic retreat of late spring snow cover (Groisman et al. 2006). For example, over the past $20 \mathrm{yr}$, the seasonal snow-covered area in the Tien Shan Mountains decreased by $15 \%$. Furthermore, an earlier shift from snowfall to rainfall in spring accelerated the rate of snow cover decrease because of decreased heat expenditure for the snowmelt (Aizen et al. 2007).

\section{Changing precipitation patterns.}

During the past $70 \mathrm{yr}$, areas of northern Eurasia east of the Ural Mountains and including northeastern China became significantly drier,

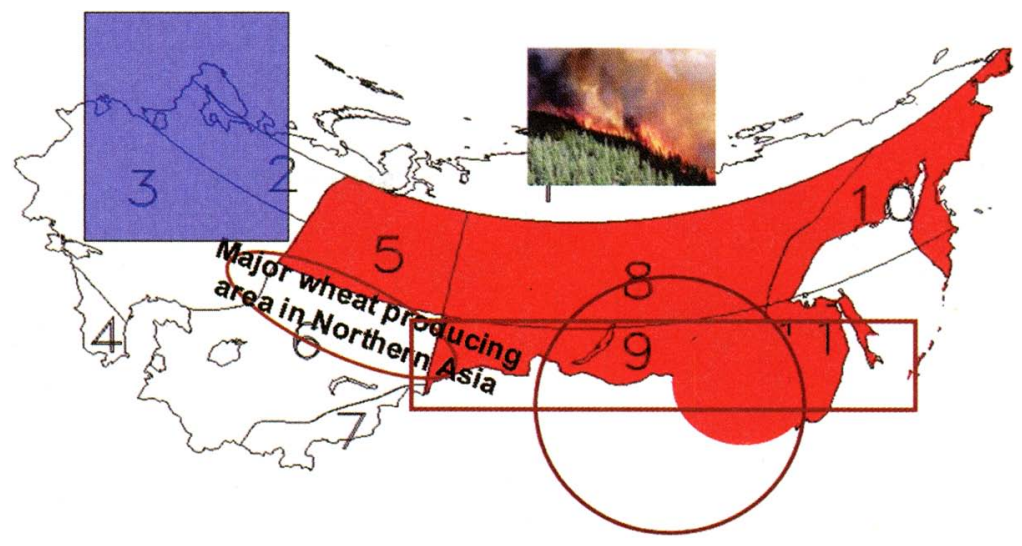

FIG. 5. Changes in the surface water cycle over northern Eurasia that have been statistically significant in the twentieth century. A composite of results of Mescherskaya and Blazhevich (1997 updated), Dai et al. (2004), Zhai et al. (2005), Niu et al. (2007), Groisman et al. (2005, 2007a), and Zolina et al. (2005). Regions with more humid conditions (blue), where potential forest fire danger has increased in the twentieth century (red), where agricultural droughts have increased (circled), and where prolonged dry episodes have increased (rectangled). while the European part of northern Eurasia, especially its northwestern part, became notably wetter (Fig. 5). Precipitation, a sizeable fraction of which falls and is stored throughout the winter as snow in the high latitudes, is a key component of the land surface water cycle. Climate change alters the timing, form, and quantity of precipitation, whichmuch more than temperature-controls runoff in Central Asia. In some plausible scenarios of future climate change, maximum modeled runoff in the Tien Shan area increased 2.2 times, while minimum modeled runoff decreased to $55 \%$ of the current level by 2100 (Aizen et al. 2006b). The possibility of such dramatic runoff changes suggests an urgent need to develop an effective response system to address and mitigate this problem.

Land surface hydrological processes. Hydrological processes in the NEESPI domain are closely related to land cover and land use changes, such as permafrost thawing, deglaciation, deforestation, forest fires, drying of wetlands, and agricultural changes. Several NEESPI studies over the Eurasian pan-Arctic have documented significant increases in annual streamflow, winter period streamflow, and minimum daily streamflow (e.g., Adam et al. 2007). Freshwater from much of the NEESPI region flows into the Arctic Ocean; thus, changes in discharge may influence the global thermohaline circulation of the World Ocean with dramatic consequences for global climate. The causes of observed streamflow trends are, however, poorly understood (Rawlins et al. 2006), and more process-based studies will be required to understand how changes in climate, land cover, and anthropogenic factors will combine to produce future runoff and evaporation changes.

\section{SOCIETY-ENVIRONMENT INTERACTIONS.}

Among the ongoing changes in the NEESPI region that affect its peoples the most are changes in land surface hydrology that affect water supply and changes in land cover and land use that affect the functioning of pastoral and agricultural systems and dust generation. These changes are, therefore, of particular interest to NEESPI.

Water supply. Water supply is critical to the arid and semiarid regions of Central and East Asia and southern areas of Russia and Ukraine. In these regions, streamflow comes largely from the seasonal melt of snow and glaciers, which are currently retreating in response to climate change. Hydrologic model simulations using the climate change scenarios from ECHAM5 and Hadley Climate Model, version 3 (HadleyCM3) GCMs (Solomon et al. 2007) project a significant runoff decrease across most of Central Asia's lowlands (Fig. 6). With a growing population of more than 100 million people, these decreases in supply are likely to conflict with increasing water demands.

Water supplies, which are also critical to human health, are affected by land use changes as well. Changes in Central Asian land use and increases in agricultural water withdrawals have had a well-publicized effect on the region's hydrology. Perhaps the best known example is the dramatic re- 


\section{A1b 2011-2030}

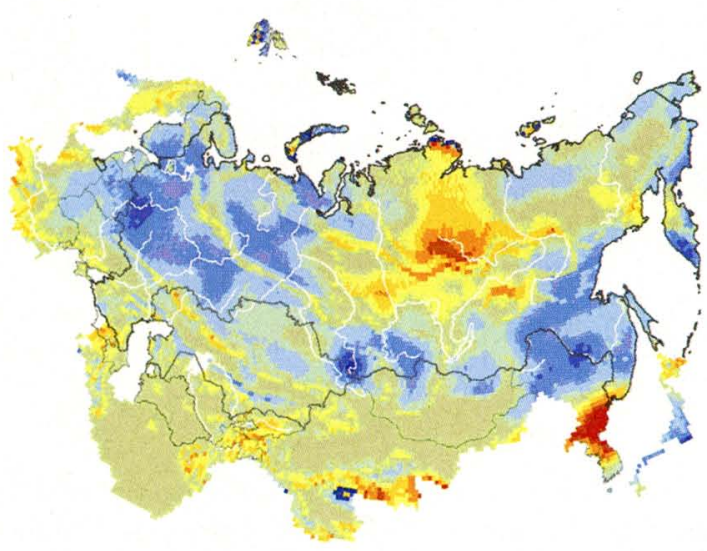

논

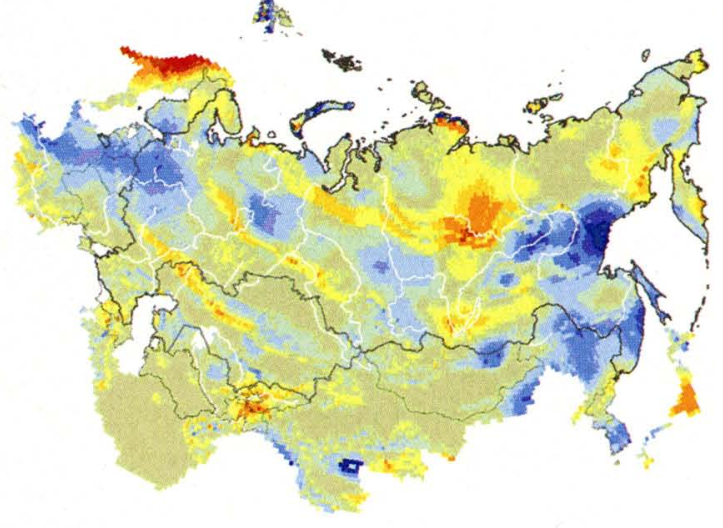

2031-2050
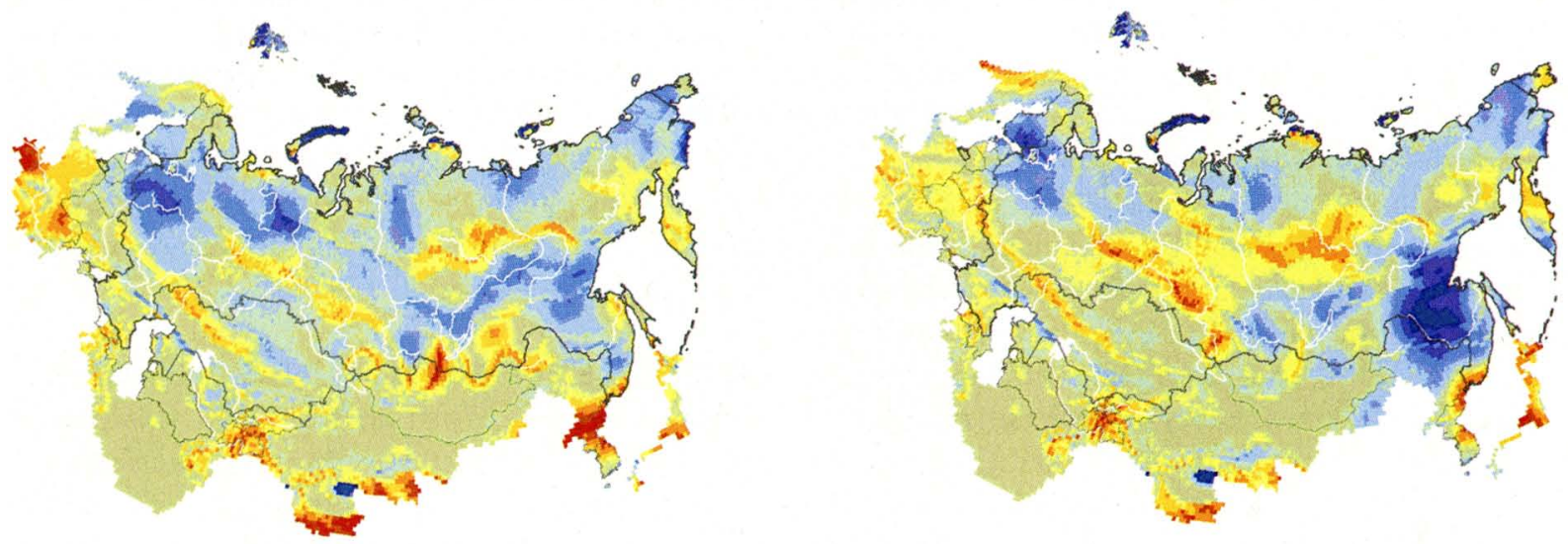

2081-2100

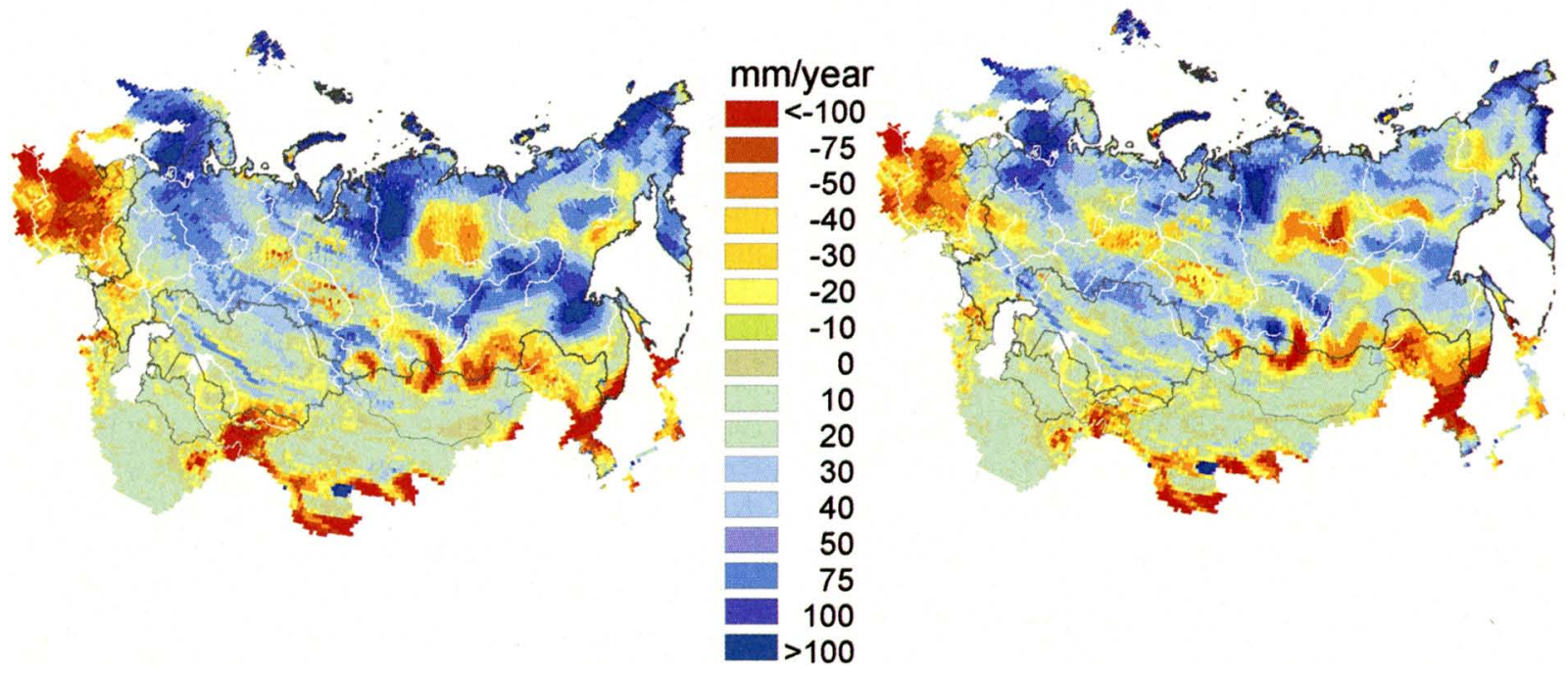

FIG. 6. Difference in model-predicted annual river runoff based on ECHAM5 GCM projections for two SRES emission scenarios (left, Alb; right BI) and model-predicted I96I-9I averaged conditions. Most significant runoff increases are projected along the Arctic Ocean coastline, in northern Europe, and the Russian Far East. A decrease in runoff is expected in most southern regions of the NEESPI domain (archive of Shiklomanov et al. 2007). 
duction in the extent and volume as well as ecological degradation of the Aral Sea over the last half century. Fewer publicized changes have occurred elsewhere in the region. Across the NEESPI Central Asian region, changes in the hydrological cycle are due to a combined effect of water use and engineering, land use/ cover change, and climate variability and change. To account for human interventions, Shiklomanov et al. (2007) simulated the operation of large reservoirs, their influence on river discharge, and the role of irrigation in Central Asia. They found that climate variability has a greater influence than water management or land cover change in shaping the hydrologic cycle over most of Central Asia. An exception is the areas of extensive irrigation in the Aral Sea and Balkhash Lake basins where water use strongly controls the hydrological cycle.

Water management appears to be critical for longterm seasonal trend analysis. To separate human and climate influences on the pan-Arctic water cycle, Adam et al. (2007) coupled the VIC hydrological model to a reservoir routing model to model pre- and post-reservoir construction differences in monthly and annual streamflow for the Lena, Yenisei, and Ob' Rivers. They found that reservoir operations had little effect on annual streamflow trends but largely determined winter streamflow changes.

Changes in climate exert a strong effect on crop growth. Dolan et al. (2006) used projected climate change scenarios to estimate the effect of future climate change on the potential crop growing regions of the Eurasian pan-Arctic. They found that the extent of areas in the pan-Arctic warm enough to support crops will increase dramatically during the next century. However, physical and chemical soil characteristics and water availability limit potential crop-producing regions. As a result, some scenarios predict a loss of a substantial fraction of current cropland in northern Kazakhstan and southern Siberia (cf. Vygodskaya et al. 2007).

Land cover/land use change and pastoral systems. Land use history of northern Eurasia is unique within the global environmental science framework as a result of political changes of the twentieth century that affected land use (e.g., collectivization and privatization). Northern Eurasia land use is highly diverse and may change very quickly. For example, over a period of only $10 \mathrm{yr}$ (1993-2002), the urban area and barrens of Inner Mongolia increased by $250 \%$ and $150 \%$, respectively, while shrub lands, temperate savannah, wetlands, and grasslands decreased by $30 \%-60 \%$ (John et al. 2008).
In the semiarid regions of the Eurasian steppe, nomadic pastoralism has been the dominant agronomic activity for many centuries. Dramatic changes occurred in pastoral systems of Mongolia, China, and Kazakhstan during the past two decades as a result of cultural, political, and economic factors. These changes and the increasing effects of climate change have altered the resilience of pastoral systems. Ojima and Chuluun (2008) argued that land use change resulting from sociopolitical changes has affected the carbon dynamics of this part of the NEESPI region more than climate change. In recent years, informal traditional pastoral and agricultural cooperatives have re-emerged after privatization from Mongolia to Moldova. Such social organization regulates land use management and safeguards against natural hazards. The effects of these policies are being evaluated using remote sensing technology (Boone et al. 2007).

In the Eurasian Arctic, the traditional practice of reindeer herding by indigenous people is being altered by climate-associated vegetation changes. Extensive anthropogenic disturbance and transformation of vegetation cover during the past $20 \mathrm{yr}$ on the Yamal Peninsula has resulted from gas and oil development and overgrazing by the Nenets' reindeer herds. Consequently, Yamal has been identified as a "hot spot" for both Arctic climate change and land use change (Forbes 1999). NEESPI researchers are using a combination of ground-based studies, remote-sensing studies, and studies of the Nenets' land use activities to develop vegetation-change models (cf., www. geobotany.uaf.edu/yamal/index) that can be used to predict future states of the tundra. Space-based measurements of normalized difference vegetation index (NDVI; a measure of photosynthetic activity) along the climate gradient in both North America and Eurasia show clear latitudinal trends. NDVI has increased during the last $20 \mathrm{yr}$ along most of the pan-Arctic and appears to correspond to decreases in near-shore sea-ice concentrations and increases in land surface temperatures (Bhatt et al. 2007). Models using the results from the Yamal and a comparable transect in North America are being used to project the long-term changes in biomass for plant functional types of the Arctic (Fig. 7).

Land cover/land use, climate, and dust and air pollutants. Various land cover and land use changes in northern Eurasia have also affected the source regions of windblown dust as well as other particulate air pollutants. The potential for atmospheric dust to cause adverse effects on ecosystem and human health, in addition 
to exerting radiative forcing upon the Earth's climate, has been appreciated for some time. The effects of dust storms are not only regional but may also affect areas thousands of kilometers from their source, making interactions between climate change, land use, and dust aerosols globally relevant. Growing evidence suggests that changes in land use/land cover and atmospheric dust loadings are among the key

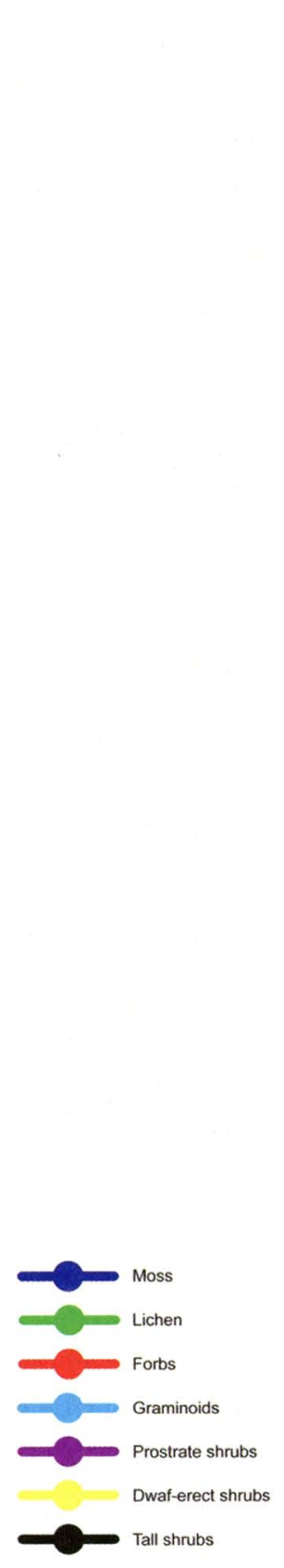

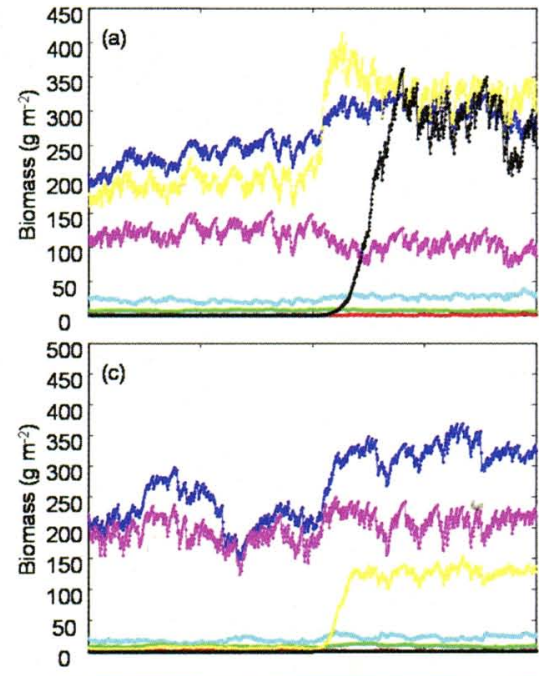
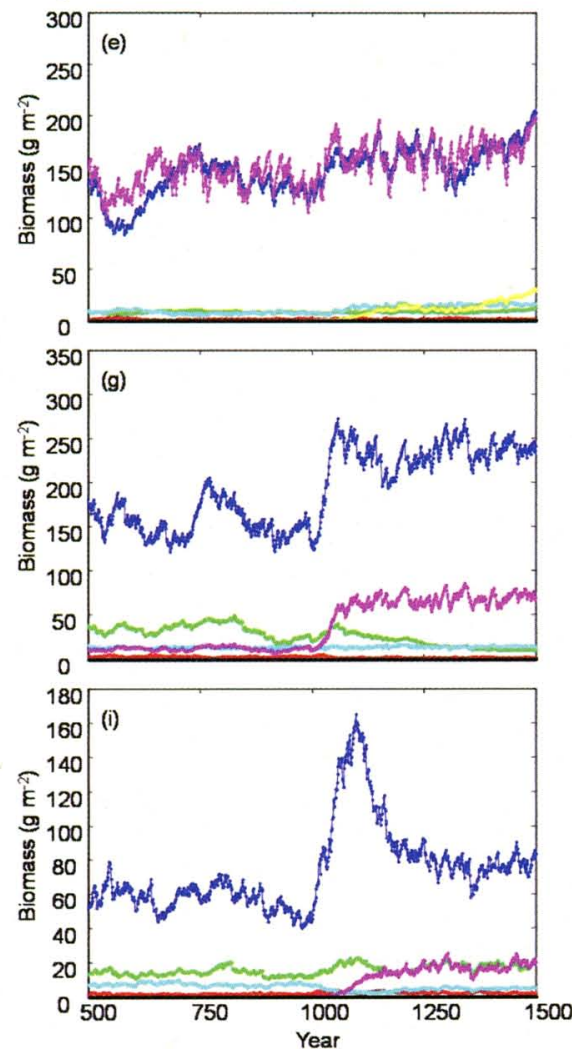
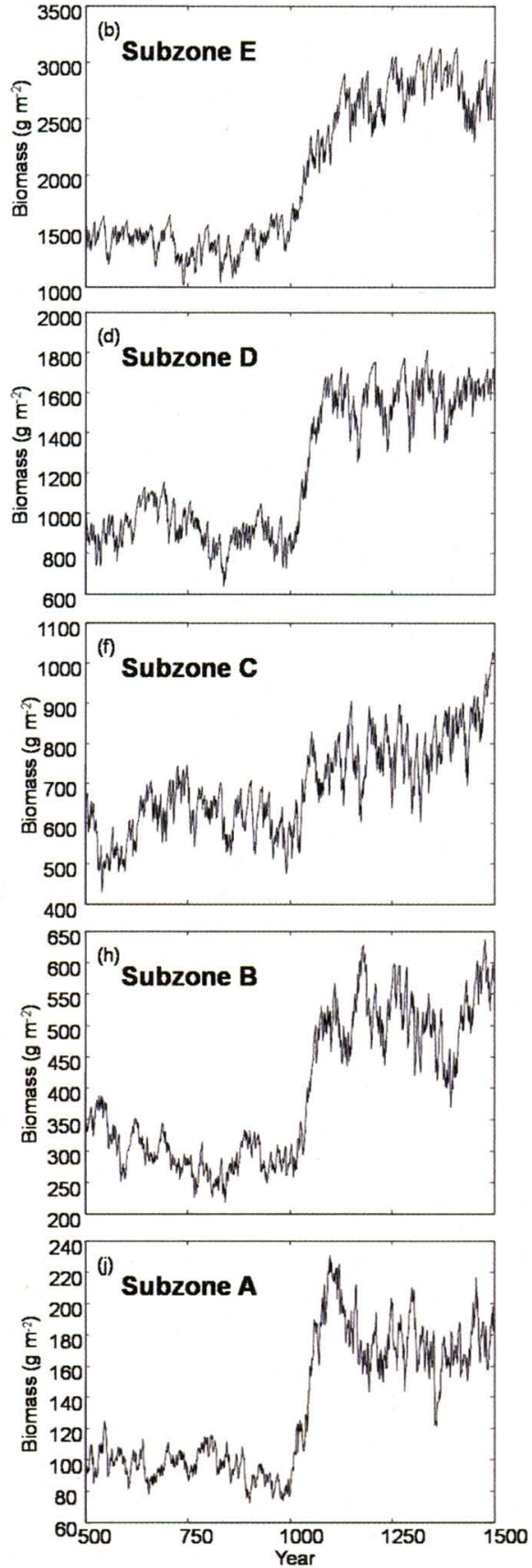

Fig. 7. Projections of Arctic plant types and total biomass response to $+2^{\circ} \mathrm{C}$ warming in the years 1000-1050 (from the beginning year of model-run initiation) in the five Arctic bioclimate subzones using the ArcVeg model (Epstein et al. 2007). Above-ground biomass is shown for (left) different plant types and total biomass including (right) below-ground biomass for zonal plant communities in bioclimate subzones (a), (b) E; (c), (d) D; (e), (f) C; (g), (h) B; and (i), (j) A. Note the change in the vertical scale for biomass as the biomass declines in response to temperature-from warm summer temperatures in subzone $E$ (southernmost subzone) to colder temperatures in subzone $A$ (northernmost subzone). Key plant limits that define the subzones are A: cushion forb; B: prostrate dwarf-shrub; C: hemiprostrate dwarf-shrub; D: erect dwarf-shrub; and E: low shrub (Walker et al. 2005). 
drivers of observed climate change for the NEESPI region. Desiccation of the Aral Sea, conversion of the steppe in Kazakhstan to agricultural fields, and severe desertification of northeast China are just a few examples of land use changes that have altered the source and emission of dust (Darmenova and Sokolik 2007). To improve the ability to predict effects of dust on the climate and environment, NEESPI researchers are developing a regional dust modeling system for Central and East Asia. This includes the development and implementation of the new dust module DuMo into the National Center for Atmospheric Research (NCAR) Weather Research and Forecasting (WRF) model (K. Darmenova et al. 2009, unpublished manuscript). The new dust module includes two different stateof-the-art schemes that explicitly account for land properties and meteorology and thus improve modeling capability. The coupled regional modeling system WRF-DuMo is currently used by NEESPI researchers to assess the dynamics of dust emission and associated dust effects on the energy balance and ecosystem functioning in Central Asia (Sokolik et al. 2006).

An in-depth analysis of 50-yr ground-based visibility and current weather observations from meteorological stations located in Central and East Asia revealed complex patterns of spatial and temporal distributions of dust events (Kurosaki et al. 2007). In particular in the Aral Sea region, a decrease in dust storm frequency was found (Fig. 8), indicating that an increase in the extent of the dust source (resulting from the desiccation of the Aral Sea) does not necessarily result in an increase of dust storms. A decrease in near-surface wind speeds over steppe regions of southern Russia and Kazakhstan may counterbalance the increase in dust source extent (Darmenova and Sokolik 2007). Still, increasing trends in moderate dust outbreaks are apparent (Fig. 8), pointing to further severe health problems in the region caused by dust and desertification in general.

Like dust, pollen is a health hazard and responsible for allergy-related diseases, such as asthma, rhinitis, and atopic eczema. In industrialized European countries, up to $15 \%$ of the population, particularly chil-

dren and adolescents, are sensitive to pollen allergens (World Health Organization 2003). Well-established evidence also indicates that the long-range transport (LRT) of pollen from distant regions can significantly modify local allergy seasons in many European regions by increasing atmospheric pollen concentrations before the start or after the end of local flowering (Corden et al. 2002). Analyzing and forecasting of the pollen LRT episodes requires the proper treatment of both biological and meteorological mechanisms that control its release to the atmosphere, followed by dispersion and transformation across large areas. The international Pollen Project, which is affiliated with NEESPI, brings together scientists from northern Europe (http://pollen.fmi.fi/). It aims to develop, evaluate, and apply a regional-to-continental pollen emission and transport model based on the Air Quality and Emergency Modelling System (SILAM; http://silam.fmi.fi). Research conducted under Pollen has shown that pollen grains can be treated similarly to atmospheric aerosols despite their relatively large sizes. A new pollen transport model developed within the Pollen Project is capable of generating reasonable continental-scale pollen maps (Siljamo et al. 2008).

Several NEESPI projects study the formation of air pollutants in northern Eurasia and their long-range transport. For example, within the mega project Trans-Siberia Observations into the Chemistry of the Atmosphere (TROICA), which is currently affiliated with NEESPI, Russian railroads and ships sailing northward along the major Siberian rivers provide unique platforms for gathering information on the atmospheric chemistry in the remote areas and urban megalopolises (cf. Kuokka et al. 2007; Elansky et al. 2007). Using historical data, recent satellite technologies, and transport models, NEESPI 
researchers also attempt to quantify the frequency of intrusions of Asian dust and smoke from boreal forest fires into the Arctic (Sokolik et al. 2009). Modeling and observational studies have provided evidence that atmospheric aerosols are linked to major processes that affect the atmosphere, cryosphere, land, and ocean, and hence have played at least some role in the changes occurring in the Arctic in recent decades.

NEESPI societal needs research. NEESPI research in the societal needs area falls into three general areas:

1) Applied social science research, which includes research that mostly addresses environmental processes and long-term regional and global change. These studies represent a majority of NEESPI societal needs research. Scientists involved in this type of study target the strategic needs of society that are most difficult to address (e.g., changes in ecosystem patterns). The outputs of these studies do not constitute applications research per se but rather serve as the starting point for bridging studies. The fact that this research is removed from the political sphere lends it greater credibility when policy conflicts occur. For instance, NEESPI multidisciplinary researchers are working together to create a suite of Earth System models to fill the gaps in our understanding of the role of northern Eurasia in global change. This tool will have numerous applications for the needs of population in the NEESPI domain. In this instance, researchers are seeking to develop the best possible science within their areas of expertise to support decisions that may affect the well-being of a given region, nation, group of nations, or society as a whole.

2) Community participation in joint efforts to address specific societal or regional objectives. A key aspect of such projects is the investment into scientific infrastructure and the training of local specialists. The Permafrost Monitoring and Circumpolar Active Layer Monitoring Projects jointly sponsored by the Russian Academy of Sciences and the U.S. National Science Foundation (Nelson et al. 2004; Romanovsky et al. 2007) are two examples of such projects. These projects support studies that assess future infrastructure stability across the entire eastern half of northern Eurasia. Other such projects include the expansion of the Climate Reference Network (CRN), developed by NOAA, into the Arctic; the 10-yr-long joint German-Uzbek project entitled Economic and Ecological Restructuring of Land and Water
Use in the Khorezm Region of Uzbekistan (www. khorezm.uni-bonn.de/); and operations of the international (Kyrgyz-German) Central Asian Institute for Applied Geosciences (CAIAG; www. caiag. $\mathrm{kg} /$ ).

3) Outreach seeks to address disaster-related needs. Fires, floods, droughts, typhoons, and landslides are among the natural disasters that have occurred regularly within the region in the past. More accurate and timely warnings about their occurrence (e.g., based on combining remotely sensed observations with improved short-term weather forecasts) help to save lives, support emergency response, and minimize property damage. Several ongoing NEESPI projects fall into this category, which include monitoring and projecting of forest fires, droughts, and floods (e.g., www.fire.uni-freiburg. de/GFMCnew/2008/06/06/2/200806/3_ru.htm; Fig. 9).

\section{INFORMATIONAL ASPECTS OF NEESPI.}

Changes in hydrometeorological services within the former Soviet Union and data policies of other countries within the NEESPI domain make it difficult to maintain unified datasets. Many NEESPI studies require relatively long-term homogeneous time series with fine temporal (e.g., daily and subdaily) and spatial resolutions. To cater to these users, several datasets have been created by the joint efforts of two NEESPI Science Data Support Centers for in situ information, located in Asheville, North Carolina, and in Obninsk, Russia. The NEESPI Science Data Support Center for Remote Sensing Information in Greenbelt, Maryland, has developed a system of deliverables of various remote sensing products specifically targeting the study domain and the needs of the NEESPI scientists (Leptoukh et al. 2007). Because of the diversity of research projects, NEESPI uses a distributed database architecture but with a common metadata database (www.fao.org/gtos/gofc-gold/ net-NERIN.html). Within each large cluster of the NEESPI research, separate databases have been created for regional (e.g., Siberia, Gordov et al. 2008; China, http://bcc.cma.gov.cn/en/) and topical [e.g., Arctic hydrology (www.r-arcticnet.sr.unh.edu/), cryosphere (U.S. National Snow and Ice Data Center, Boulder, Colorado), and dust (Asian Dust Databank; Kurosaki et al. 2007)] data.

Land cover information (maps) is of primary importance for terrestrial ecosystem modeling. In well-populated regions, it is possible to collect this information using in situ data (e.g., land surveys). In 
sparsely populated regions, remote sensing products must fulfill most needs. In particular, the first attempts to construct forest biomass maps at a resolution of $1 \mathrm{~km}$ using Envisat Advanced Synthetic Aperture Radar (ASAR) images are encouraging (Santoro et al. 2007). Although multiple moderate- and coarse-resolution remote sensing land cover products have been developed, their validation remains challenging for northern Eurasia, where validation sites are sparse, several land cover types are unique, and ecosystem disturbances and land cover changes are widespread. Therefore, NEESPI researchers analyze the performance of available land cover maps for northern Eurasia (e.g., Frey and Smith 2007). The disagreement among the maps is significant. For example, the estimates of forest biomass in the forests of Russia differed by $30 \%$ depending on the base map (Houghton et al. 2007). A map cross comparison over the entire northern Eurasia region is in progress, and a network of 15 sites has been established for validation of existing and new maps of land cover, land cover changes, and disturbances. These test sites are the size of approximately $180 \mathrm{~km} \times$ $180 \mathrm{~km}$ each and will also serve as case studies of land cover histories across northern Eurasia.

\section{FROM MONITORING AND PROCESS} STUDIES TO REGIONAL PROJECTIONS.

The first group of NEESPI projects has mostly focused on assembling regional databases (e.g., Leptoukh et al.
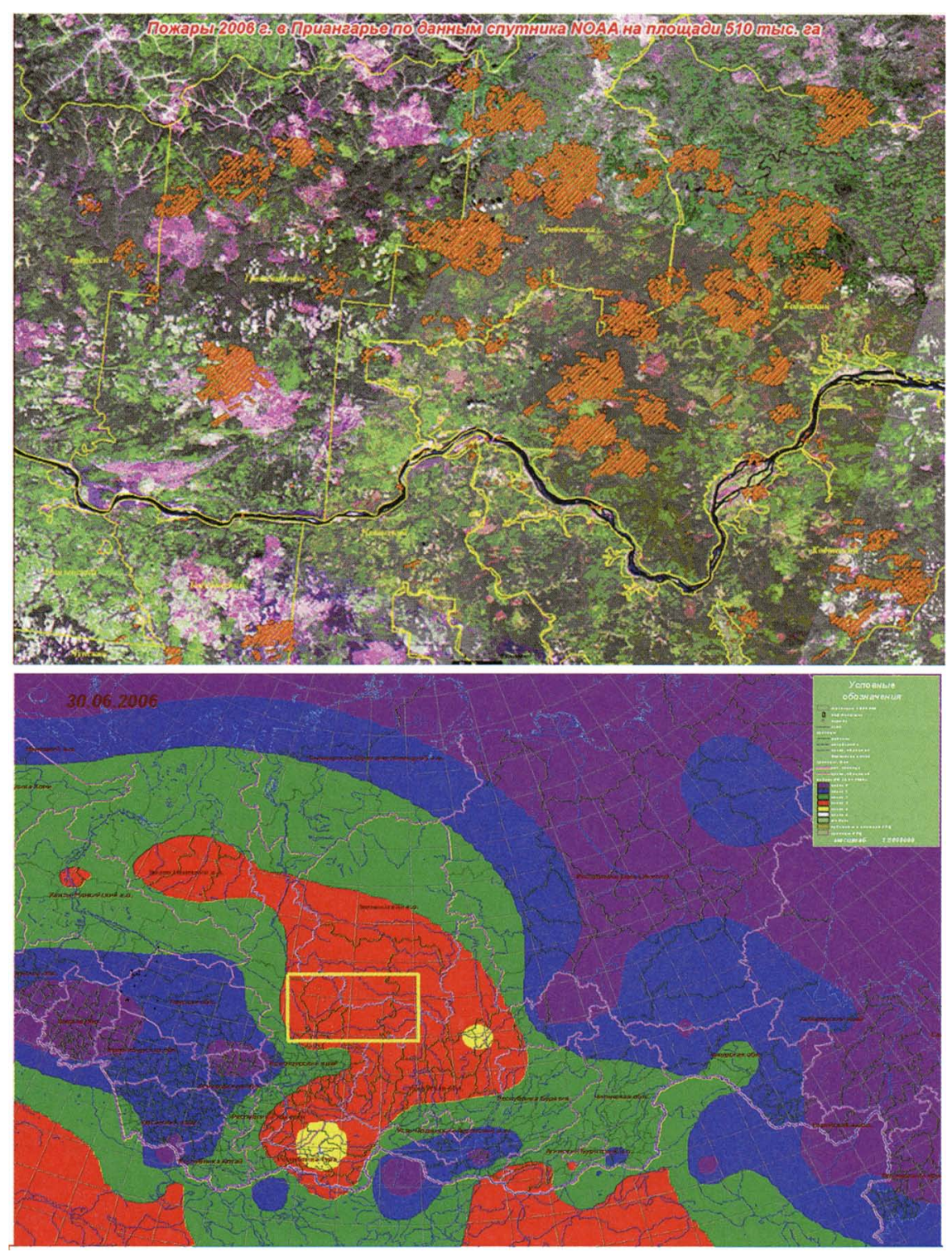

Fig. 9. (top) Fires (orange) near the Angara River in the Krasnoyarsk region of central Siberia in summer 2006, as reported by the NOAA Advanced Very High Resolution Radiometer (AVHRR). The total burned area in this image is 510,000 ha. (bottom) Meteorological fire danger index (MFDI; Vonsky and Zhdanko 1976) for the Asian part of Russia, 30 Jun 2006. Color codes of the index plot are yellow: extreme fire danger (MFDI $\geq 20000$ ); red: very high fire danger ( $10000<$ MFDI $\geq 20000)$; green: high fire danger (3000 < MFDI $\geq 10$ 000); blue: moderate fire danger ( $1000<$ MFDI $\geq 3000)$; and violet: low fire danger $(300<$ MFDI $\geq 1000)$. The yellow rectangle in the zone of relatively high fire hazard highlights the region along the Angara River shown in the top plate (Sukhinin and McRae 2008).

2007; NCDC 2008), organizing improved environmental monitoring of the region (e.g., Loboda et al. 2007; Romanovsky et al. 2007, 2008), and studies of individual environmental processes (e.g., Khan et al. 2007; Smith et al. 2007). This has been a necessary step to address challenges that emerged in the region with rapidly and simultaneously changing climate, 
environmental, and societal systems. Some of these efforts have not yet been completed, but as shown in Fig. 5, we already see a general picture of changes taking place within the NEESPI domain (see also Fig. 2; de Beurs and Henebry 2008; Bulygina et al. 2007; Lammers et al. 2007).

A clear understanding of the gaps in our knowledge of environmental changes in the NEESPI domain and consequent systematic addressing/resolving them were one of the intangible major achievements of the first stage of NEESPI. The NEESPI projects have since begun to consolidate spatially extensive projections of the consequences of regional-scale processes, such as wildfires (Soja et al. 2007 and McRae et al. 2006), soil carbon storage (Ojima and Chuluun 2008), forest dynamics (Shugart et al. 2006), permafrost change (Romanovsky et al. 2007, 2008), and methane generation (Bohn et al. 2007) into a regional ecosystem understanding. At the same time, intense field campaigns using fine scale measurements of material and energy fluxes (e.g., Elansky et al. 2007; Georgiadi and Zolotokrylin 2007; Houghton et al. 2007; Kurbatova et al. 2008; Peregon et al. 2008; Shakhova et al. 2007; Walter et al. 2006) have begun providing locations and tools for testing these regional projections.

Early NEESPI findings have been used by Intergovernmental Panel on Climate Change (IPCC) Working Groups 1 and 2 in preparation of the IPCC's Fourth Assessment Report (Solomon et al. 2007) and by the Russian Federal Service for Hydrometeorology and Environmental Monitoring in preparation of the Assessment Report on Climate Change and its Consequences in Russian Federation (http:// climate2008.igce.ru/). About half of the current NEESPI studies address issues in the high-latitude part of the NEESPI domain. As a consequence, the NEESPI investigations remain the backbone of several International Polar Year (IPY) activities (in particular, IPY activity \#138-Cold Land Processes in the Northern Hemisphere Continents and their Coastal Zone: Regional and Global Climate and Societal-Ecosystem Linkages and Interactions) and are positioning themselves to secure success for the newly established Arctic Council's assessment of the Arctic cryosphere in Report "Climate Change and the Cryosphere: Snow, Water, Ice, and Permafrost in the Arctic."

More recently, the NEESPI research focus has begun to shift toward modeling and its ability to project the future state of climate, the environment, and societies in the NEESPI domain (e.g., Aizen et al. 2007; Bohn et al. 2007; Goetz et al. 2007; Romanovsky et al. 2008; Shkolnik et al. 2008; Stendel et al. 2007;
Vygodskaya et al. 2007). This new focus requires a higher level of integration than in previous NEESPI studies. In a modeling context, it is not sufficient to describe a given envirionmental or societal process. This process should be linked to other processes to assess its actual role in the Earth System. Thus, modeling becomes an engine of integration of diverse regional studies. The effort within NEESPI to incorporate applications and societal needs research presents additional challenges. We believe, however, that the motivation is there and that significant progress has already been made toward improving understanding of key dynamic processes within the region. We also believe that is the first critical step toward understanding not only the functioning of the region's biogeochemical, energy, and water cycles but also the role of humans in a rapidly changing, and vitally important, region.

ACKNOWLEDGMENTS. The idea and commitment to prepare this paper were conceived at the workshop Northern Eurasia Land Surface Properties and Change and Its Role in the Global Earth System, held at the Aspen Global Change Institute (AGCI), Aspen, Colorado, in August 2007 (Groisman et al. 2007b) with support from NASA, NSF, and DOE for the AGCI 2007 summer institutes. Thoughtful comments and suggestions of four anonymous reviewers were highly appreciated.

\section{REFERENCES}

Adam, J. C., and D. P. Lettenmaier, 2008: Application of new precipitation and reconstructed streamflow products to streamflow trend attribution in northern Eurasia. J. Climate, 21, 1807-1828.

— I. Haddeland, F. Su, and D. P. Lettenmaier, 2007: Simulation of reservoir influences on annual and seasonal streamflow changes for the Lena, Yenisei and Ob' rivers. J. Geophys. Res., 112, D24114, doi:10.1029/2007JD008525.

Aizen, E. M., V. B. Aizen, J. M. Melack, and A. N. Krenke, 2000: Heat exchange during snow ablation in plains and mountains of Eurasia. J. Geophys. Res., 105 (D22), 27 013-27 022.

Aizen, V. B., E. M. Aizen, A. B. Surazakov, and V. A. Kuzmichenok, 2006a: Glacier changes in central and northern Tien Shan during the last 140 years based on surface and remote-sensing data. Ann. Glaciol., 43, 202-213.

— _ _ and V. A. Kuzmichenok, 2006b: Geoinformational simulation of possible changes in Central Asian water resources. Global Planet. Change, 56, 341-358. 
- - — changes in the Tien Shan: Simulation and prediction. Environ. Res. Lett., 2, 045019, doi:10.1088/17489326/2/4/045019.

Baker, S. P., and W. M. Hao, 2005: Fire emissions from Scotch Pine forest in Central Siberia. Eos, Trans. Amer. Geophys. Union, 86 (52); (Fall Meeting Suppl.), Abstract A21B-0844.

Betts, R. A., 2000: Offset of the potential carbon sink from boreal forestation by decreases in surface albedo. Nature, 408, 187-190.

Bhatt, U. S., D. A. Walker, M. K. Raynolds, and J. Comiso, 2007: Influence of regional sea ice variability on Arctic tundra. Proc. Seventh Int. Conf. on Global Change: Connection to the Arctic, Fairbanks, AK, International Arctic Research Center, 76-78.

Bohn, T. J., D. P. Lettenmaier, K. Sathulur, L. C. Bowling, E. Podest, K. C. McDonald, and T. Friborg, 2007: Methane emissions from western Siberian wetlands: Heterogeneity and sensitivity to climate change. Environ. Res. Lett., 2, 045015, doi:10.1088/17489326/2/4/045015.

Boone, R. B., J. M. Lackett, K. A. Galvin, D. S. Ojima, and C. J. Tucker III, 2007: Links and broken chains: Evidence of human-caused changes in land cover in remotely sensed images. Environ. Sci. Policy, 10, 135-149.

Bulygina, O. N., V. N. Razuvaev, N. N. Korshunova, and P. Ya. Groisman, 2007: Climate variations and changes in extreme climate events in Russia. Environ. Res. Lett., 2, 045020, doi:10.1088/17489326/2/4/045020.

Corden, J. M., A. Stach, and W. Milligton, 2002: A comparison of Betula pollen season at two European sites: Derby, United Kingdom and Poznan, Poland (1995-1999). Aerobiologia, 18, 45-53.

Dai, A., K. E. Trenberth, and T. Qian, 2004: A global dataset of Palmer Drought Severity Index for 18702002: Relationship with soil moisture and effects of surface warming. J. Hydrometeor., 5, 1117-1130.

Darmenova, K., and I. N. Sokolik, 2007: Assessing uncertainties in dust emission in the Aral Sea region caused by meteorological fields predicted with a mesoscale model. Global Planet. Change, 56, 297-310.

de Beurs, K. M., and G. M. Henebry, 2008: Northern annular mode effects on the land surface phenologies of northern Eurasia. J. Climate, 21, 4257-4279.

Dolan, K. A., R. B. Lammers, and C. J. Vörösmarty, 2006: Pan-Arctic temperatization: A preliminary study of future climate impacts on agriculture opportunities in the Pan-Arctic drainage system. Eos, Trans. Amer. Geophys. Union, 87 (Fall Meeting Suppl.), Abstract U33A-0026.
Dutta, K., E. A. G. Schuur, J. C. Neff, and S. A. Zimov, 2006: Potential carbon release from permafrost soils of Northeastern Siberia. Global Change Biol., 12, 2336-2351.

Elansky, N., A. Skorokhod, I. Belikov, O. Lavrova, V. Kopeikin, A. Andronova, A. Grissenko, and M. Zapevalow, 2007: TROICA-10 Experiment: Study of Moscow pollution plume by mobile railway laboratory. Geophysical Research Abstracts, Vol. 9, Abstract 01399. [Available online at www.cosis.net/abstracts/ EGU2007/01399/EGU2007-J-01399.pdf.]

Epstein, H. E., Q. Yu, J. O. Kaplan, and H. Lischke, 2007: Simulating future changes in arctic and subarctic vegetation. Comput. Sci. Eng., 9, 12-23.

Forbes, B. C., 1999: Land use and climate change on the Yamal Peninsula of north-west Siberia: Some ecological and socio-economic implications. Polar Res., 18, 367-373.

Frey, K. E., and L. C. Smith, 2007: How well do we know northern land cover? Comparison of four global vegetation and wetland products with a new groundtruth database for West Siberia. Global Biogeochem. Cycles, 21, GB1016, doi:10.1029/2006GB002706.

Georgiadi, A. G., and A. N. Zolotokrylin, 2007: Heat and Water Exchange of Permafrost Landscapes of Eastern Siberia and Their Factors (in Russian). Triada Publications, $576 \mathrm{pp}$.

Goetz, S. J., M. C. Mack, K. R. Gurney, J. T. Randerson, and R. A. Houghton, 2007: Ecosystem responses to recent climate change and fire disturbance at northern high latitudes: Observations and model results constrasting northern Eurasia and North America. Environ. Res. Lett., 2, 045031, doi:10.1088/17489326/2/4/045031.

Gordov, E., M. Kabanov, V. Lykosov, and E. Vaganov, 2008: First results of SIRS NEESPI megaproject on land-atmosphere processes in Siberia. Geophysical Research Abstracts, Vol. 10, Abstract 01198, [Available online at www.cosis.net/abstracts/EGU2008/01198/ EGU2008-A-01198.pdf.]

Groisman, P. Ya., and S. A. Bartalev, 2007: Northern Eurasia Earth Science Partnership Initiative (NEESPI): Science plan overview. Global Planet. Change, 56, 215-234.

—, R. W. Knight, D. R. Easterling, T. R. Karl, G. C. Hegerl, and V. N. Razuvaev, 2005: Trends in intense precipitation in the climate record. J. Climate, 18, 1343-1367.

- — - V. N. Razuvaev, O. N. Bulygina, and T. R. Karl, 2006: State of the ground: Climatology and changes during the past 69 years over northern Eurasia for a rarely used measure of snow cover and frozen land. J. Climate, 19, 4933-4955. 
— over Northern Eurasia: Changes during the 20th century. Global Planet. Change, 56, 371-386.

—, I. Sokolik, K. Hibbard, G. Brasseur, and J. Katzenberger, 2007b: Northern Eurasia in the global Earth system. Eos, Trans. Amer. Geophys. Union, 88, doi:10.1029/2007EO460006.

Houghton, R. A., D. Butman, A. Bunn, O. N. Krankina, P. Schlesinger, and T. A. Stone, 2007: Mapping Russian forest biomass with data from satellites and forest inventories. Environ. Res. Lett., 2, 045032 , doi:10.1088/1748-9326/2/4/045032.

Ivanova, G. A., V. A. Ivanov, E. A. Kukavskaya, S. G. Conard, and D. J. McRae, 2007: Fire influence on carbon emissions in Scots pine stands of Central Siberia (in Russian). Siberian Ecol. J., 6, 885-895.

John, R., and Coauthors, 2008: Predicting plant diversity based on remote sensing products in the semi-arid region of Inner Mongolia. Remote Sens. Environ., 112, 2018-2032.

Khan, V. M., K. G. Rubinstein, and A. B. Shmakin, 2007: Comparison of seasonal and interannual variability of snow cover in Russian watersheds according to observations and reanalyses (in Russian). Izv. Atmos. Oceanic Phys., 43, 69-80.

Korovin, G. N., and N. V. Zukkert, 2003: Climatic change impact of forest fires in Russia. Climatic Change: View from Russia, V. I. Daniov-Danilyan, Ed., TEIS Publication, 69-98.

Kuokka, S., and Coauthors, 2007: Chemical composition of atmospheric aerosols between Moscow and Vladivostok. Atmos. Chem. Phys. Discuss., 7, 7473-7508.

Kurbatova, J. A., J. C. Li, A. Varlagin, X. Xiao, and N. N. Vygodskaya, 2008: Modeling carbon dynamics in two adjacent spruce forests with different soil conditions in Russia. Biogeosciences, 5, 969-980.

Kurosaki, Y., I. N. Sokolik, and V. N. Razuvaev, 2007: Analyses of ground-based and satellite observations for developing a dust climatology in Central and East Asia. Eos, Trans. Amer. Geophys. Union, 88 (Fall Meeting Suppl.), Abstract GC23A-0978.

Lammers, R. B., J. W. Pundsack, and A. I. Shiklomanov, 2007: Variability in river temperature, discharge, and energy flux from the Russian panArctic landmass. J. Geophys. Res., 112, G04S59, doi:10.1029/2006JC000370.

Lawrence, D. M., A. G. Slater, V. E. Romanovsky, and D. J. Nicolsky, 2008: Sensitivity of a model projection of near-surface permafrost degradation to soil column depth and representation of soil organic matter. J. Geophys. Res., 113, F02011, doi:10.1029/2007JF000883.
Leptoukh, G., P. Romanov, S. Shen, T. Loboda, and I. Gerasimov, 2007: NASA NEESPI Data and Services Center for Satellite Remote Sensing Information. Environ. Res. Lett., 2, 045009, doi:10.1088/17489326/2/4/045009.

Loboda, T., K. J. O’Neal, and I. Csiszar, 2007: Regionally adaptable dNBR based algorithm for burned area mapping from MODIS data. Remote Sens. Environ., 109, 429-442.

Lugina, K. M., P. Ya. Groisman, K. Ya. Vinnikov, V. V. Koknaeva, and N. A. Speranskaya, 2006: Monthly surface air temperature time series area-averaged over the 30-degree latitudinal belts of the globe, 1881-2005. Trends: A Compendium of Data on Global Change. [Available online at http://cdiac.ornl.gov/ trends/temp/lugina/data.html.]

McRae, D. J., and Coauthors, 2006: Variability of fire behavior, fire effects, and emissions in Scotch Pine forests of Central Siberia. Mitigation Adapt. Strategies Global Change, 11, 45-74.

Meleshko, V. P., V. M. Kattsov, V. A. Govorkova, P. V. Sporyshev, I. M. Shkollnik, and B. E. Shneerov, 2008: Climate of Russia in the 21st century. Part 3. Future climate changes calculated with an ensemble of coupled atmosphere-ocean general circulations CMIP3 models (in Russian). Meteor. Gidrol., 33, No. 9, 5-21.

Mescherskaya, A. V., and V. G. Blazhevich, 1997: The drought and excessive moisture indices in a historical perspective in the principal grain-producing regions of the former Soviet Union. J. Climate, 10, 2670-2682.

NCDC, 2008: Global Daily Climatology Network: Kazakhstan, 17 pp. [Available from NOAA National Climatic Data Center, 151 Patton Avenue, Asheville, NC 28801 and available online at wwwl.ncdc.noaa. gov/pub/data/documentlibrary/tddoc/td9814.pdf.]

Nelson, F. E., N. I. Shiklomanov, H. H. Christiansen, and K. M. Hinkel, 2004: The circumpolar-activelayer-monitoring (CALM) workshop: Introduction. Permafrost Periglacial Processes, 15, 99-101.

Niu, R. Y., P. M. Zhai, and W. M. She, 2007: The applied research of forest fire danger weather index. Quart. J. Appl. Meteor., 18, 479-489.

Ojima, D. S., and T. Chuluun, 2008: Policy changes in Mongolia: Implications for land use and landscapes. Fragmentation in Semi-Arid and Arid Landscapes Consequences for Human and Natural Systems, K. A. Galvin et al., Eds., Springer, 179-193.

Patra, P. K., S. Maksyutov, M. Ishizawa, T. Nakazawa, J. Ukita, and T. Takahashi, 2005: Interannual and decadal changes in the sea-air $\mathrm{CO}_{2}$ flux from atmospheric $\mathrm{CO}_{2}$ inverse modeling. Global Biogeochem. Cycles, 19, GB4013, doi:10.1029/2004GB002257. 
Peregon, A., S. Maksyutov, N. Kosykh, and N. Mironycheva-Tokareva, 2008: Map-based inventory of wetland biomass and net primary production in western Siberia. J. Geophys. Res., 113, G01007, doi:10.1029/2007JG000441.

Rawlins, M. A., C. J. Willmott, A. Shiklomanov, E. Linder, S. Frolking, R. B. Lammers, and C. J. Vörösmarty, 2006: Evaluation of trends in derived snowfall and rainfall across Eurasia and linkages with discharge to the Arctic Ocean. Geophys. Res. Lett., 33, L07403, doi:10.1029/2005GL025231.

Romanovsky, V. E., T. S. Sazonova, V. T. Balobaev, N. I. Shender, and D. O. Sergueev, 2007: Past and recent changes in air and permafrost temperatures in Eastern Siberia. Global Planet. Change, 56, 399-413.

- , and Coauthors, 2008: Thermal state and fate of permafrost in Russia: First results of IPY. Proc. Nineth Int. Conf. on Permafrost, Fairbanks, AK, International Permafrost Association, 1511-1518.

Santoro, M., U. Wegmüller, and A. Wiesmann, 2007: Possibilities of mapping growing stock volume of boreal forest using multitemporal ENVISAT ASAR WS and GM observations. Proc. Fifth Int. Symp. on Retrieval of Bio-and Geophysical Parameters from SAR Data for Land Applications, Bari, Italy, European Space Agency, CD-ROM.

Schulze, E.-D., and Coauthors, 2002: The Eurosiberian transect: An introduction to the experimental region. Tellus, 54B, 421-428.

Shakhova, N. E., I. P. Semiletov, A. N. Salyuk, N. N. Bel'cheva, and D. A. Kosmach, 2007: Methane anomalies in the near-water atmospheric layer above the shelf of East Siberian Arctic shelf (in Russian). Dokl. Akad. Nauk, SSR, 414, 819-823. (English translation in Dokl. Earth Sci., 415, 764-768.)

Shiklomanov, A. I., R. B. Lammers, M. A. Rawlins, L. C. Smith, and T. M. Pavelsky, 2007: Temporal and spatial variations in maximum river discharge from the new Russian data set. J. Geophys. Res., 112, G04S53, doi:10.1029/2006JG000352.

Shkolnik, I. M., E. K. Molkentin, E. D. Nadezhina, E. I. Khlebnikova, and I. A. Sall, 2008: Temperature extremes and wild fires in Siberia in the 21st century: The MGO regional climate model simulation (in Russian). Meteor. Gidrol., 33, No. 3, 5-15.

Shugart, H. H., J. K. Shuman, X. Yan, and N. Zhang, 2006: Eurasian forest cover and climate feedbacks. iLEAPS Newsletter, No. 3, iLEAPS International Project Office, Helsinki, Finland, 20-21.

Siljamo, P., and Coauthors, 2008: Representatives of point-wise phonological Betula data observed in different parts of Europe. Global Ecol. Biogeogr., 17, 489-502.
Smith, L. C., T. M. Pavelsky, G. M. MacDonald, A. I. Shiklomanov, and R. B. Lammers, 2007: Rising minimum daily flows in northern Eurasian rivers: A growing influence of groundwater in the highlatitutde water cycle. J. Geophys. Res., 112, G04S47, doi:10.1029/2006JG000327.

Soja, A. J., W. R. Cofer, H. H. Shugart, A. I. Sukhinin, P. W. Stackhouse Jr., D. J. McRae, and S. G. Conard, 2004: Estimating fire emissions and disparities in boreal Siberia (1998-2002). J. Geophys. Res., 109, D14S06, doi:10.1029/2004JD004570.

— , and Coauthors, 2007: Climate-induced boreal forest change: Predictions versus current observations. Global Planet. Change, 56, 274-296.

Sokolik, I. N., R. Dickinson, and Y. Dai, 2006: Impact of atmospheric mineral dust on the surface energy balance and PAR in the NEESPI study domain. Eos, Trans. Amer. Geophys. Union (Fall Meeting Suppl.), Abstract GC21B-05.

—, J. A. Curry, and V. Radionov, 2009: Interactions of Arctic aerosols with land cover and land use changes in Northern Eurasia and their role in the Arctic climate system. Arctic Land Cover and Land Use in a Changing Climate: Focus on Eurasia, G. Gutman and A. Reissel, Eds., Springer, in press.

Solomon, S., D. Quin, M. Manning, M. Marquis, K. Averyt, M. M. B. Tignor, H. L. Miller Jr., and Z. Chen, Eds., 2007: Climate Change 2007: The Physical Science Basis. Cambridge University Press, 996 pp.

Stendel, M., V. E. Romanovsky, J. H. Christensen, and T. S. Sazonova, 2007: Global warming and permafrost: Closing the gap between climate model simulations and local permafrost dynamics. Global Planet. Change, 56, 203-214.

Sukhinin, A. I., A. J. Soja, and D. J. McRae, 2008: Space monitoring and analysis of catastrophic fires in Central Siberia. Geophysical Research Abstracts, Vol. 10, Abstract 11915. [Available online at www.cosis.net/ abstracts/EGU2008/11915/EGU2008-A-11915.pdf.]

Vonsky, S. M., and V. A. Zhdanko, 1976: Principles of Elaboration of Meteorological Forest Fire Danger Indices: Methodological Recommendations (in Russian). LenNIILH, 48 pp.

Vygodksaya, N. N., P. Ya. Groisman, N. M. Tchebakova, J. A. Kurbatova, O. Panfyorov, E. I. Parfenova, and A. F. Sogachev, 2007: Ecosystems and climate interactions in the boreal zone of northern Eurasia. Environ. Res. Lett., 2, 045033, doi:10.1088/17489326/2/4/045033.

Walker, D. A., and Coauthors, 2005: The circumpolar Arctic vegetation map. J. Veg. Sci., 16, 267-282.

Walter, K. M., S. A. Zimov, J. P. Chanton, D. Verblya, and F. S. Chapin, 2006: Methane bubbling from Siberian 
thaw lakes as a positive feedback to climate warming. Nature, 443, 71-75.

World Health Organization, 2003: Phenology and Human Health: Allergic Disorders. WHO Rep., 55 pp.

Yan, X., and H. H. Shugart, 2005: A forest gap model to simulate dynamics and patterns of Eastern Eurasian forests. J. Biogeogr., 32, 1641-1658.

Zhai, P., X. Zhang, H. Wan, and X. Pan, 2005: Trends in total precipitation and frequency of daily precipitation extremes over China. J. Climate, 18, 1096-1108.

Zolina, O., C. Simmer, A. Kapala, and S. K. Gulev, 2005: On the robustness of the estimates of centennialscale variability in heavy precipitation from station data over Europe. Geophys. Res. Lett., 32, L14707, doi:10.1029/2005GL023231.

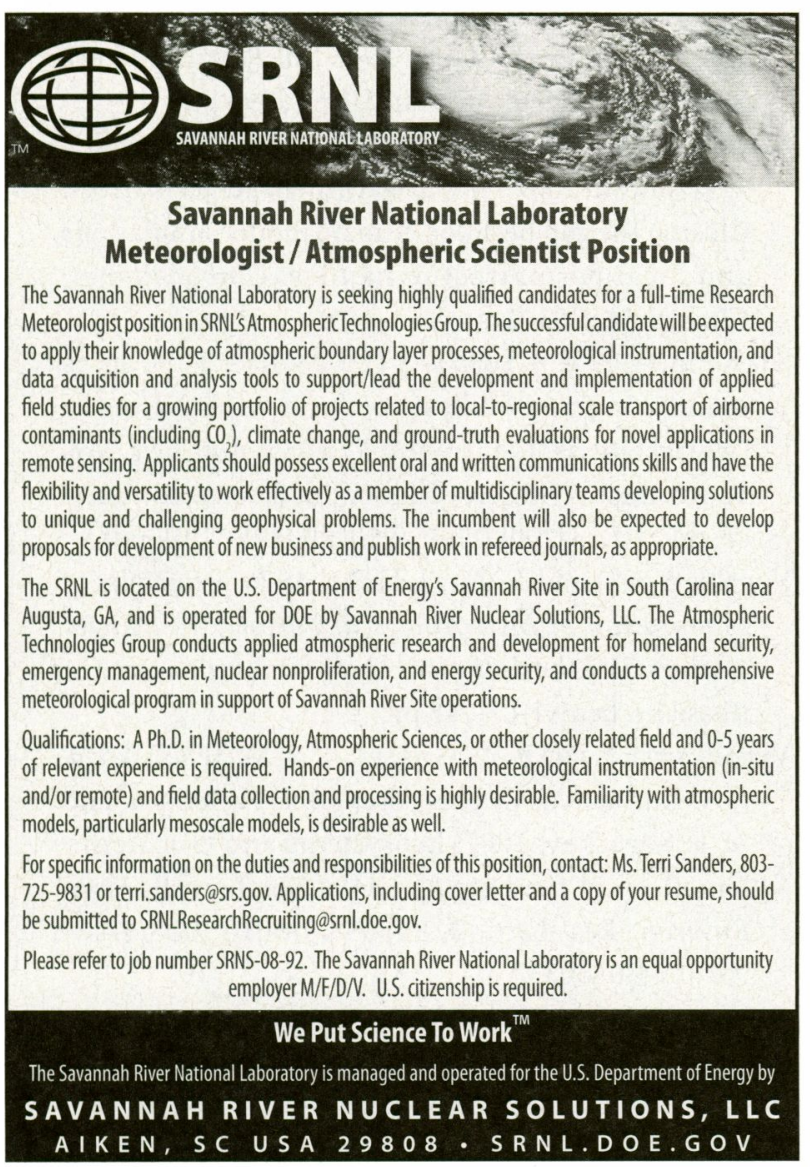

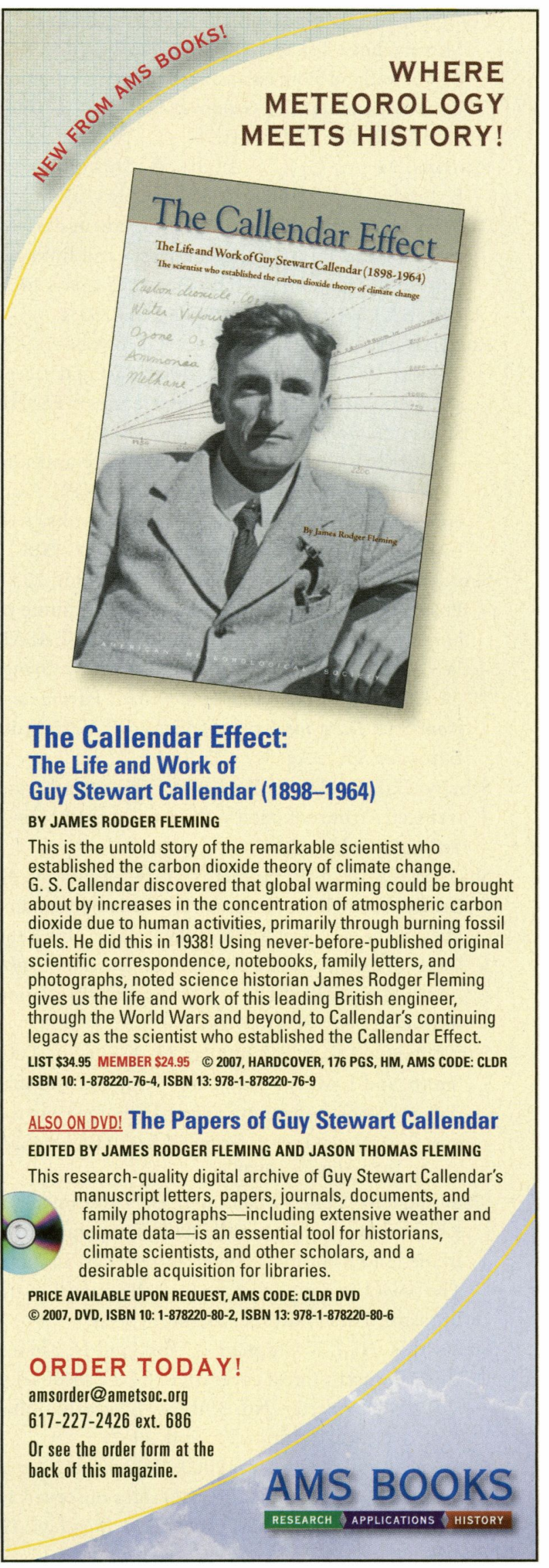

